\title{
A COMMONSENSE APPROACH TO AMPUTEE CHECK-OUT
}

\author{
J. F. NORTH* and D. W. STUART $\dagger$
}

\begin{abstract}
Noukeurige evaluering van die pasient en sy kunsis 'n uiters belangrike deel van die aanpassingsledemaat is ' $n$ Algemene benadering word toegepas wat peskik is om elke pasientersoek van die pasient voor die kinsledemaat gepas word, woriewe deelname om enige probleme by $n$ vroee stadium gelewer om die getal nuwe spreek. Statistiek getal ou pasiente te vergelyk.
\end{abstract}

Introduction

Rehabilitation of the amputee is improved if a clinic Rehaproach is used and both the patient and the team anproach carefully checked out. In many ways the orosthesis arocedure is simple, but the number of proseach conhetic variations emporat and a host of indiscriminately named new materials and cloud the device in a veneer of components which complexity. There are, however, a number of technical complesich apply to any prosthetic design and major factors whichible to develop a commonsense aptherefore the checkout procedure which will be applicable in every case.

It is suggested that the key factors in any checkout re: donning, suspension, comfort, stability, function, cosmesis, workmanship and patient satisfaction. To elaborate on these factors, a number of questions are posed to highlight the procedure.

\section{Donning}

Can the amputee don the prosthesis?

The amputee must be able to don his appliance correctly by himself and get it right every time. There is definite technique for every appliance and it involves placing the stump in a suitable position for entry into the prosthetic socket.

Below-knee appliances are normally better donned in a seated position where movement of the knee permits easy entry into the socket. Donning a below-knee prosthesis is a very straightforward technique and amputees ind it relatively easy.

Above-knee appliances are better donned in a stand ing position because this places the stump in the optimum position for entry into the socket. The donning procedure is therefore more complicated than for a below-knee appliance and it is more time-consuming and energy-taxing.

With the advent of the suction socket the donning technique has become more intricate. The stump is fed into the socket using a length of bandage which is wrapped around the stump. The bandage is fed down through the suction release valve in the distal end of the socket and is pulled through to feed the stump into the socket. The technique requires practice to achieve repeated success.

\section{Suspension}

Is the prosthesis adequately suspended?

Suspension is necessary because the forces generated

* B.Sc. (Hons.) Dundee, Ph.D. (Strathclyde) Senior Lecturer in Bioengineering, University of Cape Town. $\uparrow$ Senior Technician, Department of Medical Physics and Nuclear Medicine. during the swing phase of walking tend to pull the appliance off the stump. There are a number of suspension techniques available and they use straps, belts, cuffs or suction depending upon the level of the amputation. It is not necessary to know every individual system because they are all essentially similar in that they all apply suspension forces to some portion of the anatomical structure, such as the condyles, soft tissues, or shoulders.

The suspension technique must not interfere with prosthetic function in sitting and walking. It also must be comfortable and not cause tissue abrasion in use.

In some cases the suspension passes over sensitive regions, e.g. scar tissue or hernias and great care has to be exercised.

\section{Comfort}

Is the prosthesis comfortable?

Comfort is important to the amputee. Poor prosthetic fitting will not produce a comfortable socket and pain can be generated in areas of the stump. It is quite difficult to define socket comfort, as there will be some initial discomfort until the amputee becomes used to the socket. It is very important, therefore, to check for comfort a number of times during the procedure.

The stump should be examined carefully after ambulation to detect areas of high pressure and reddening of the soft tissues. Pain usually occurs at the distal end of the stump and at those points where the weight is being carried. A burning sensation is experienced by the amputee when muscles are constrained too tightly by the socket and at points where soft tissue-rolls form at the socket rim. Discomfort can be caused by poor donning of the prosthesis and this should be carefully checked out if the socket is very uncomfortable.

Some sockets can fit beautifully when first applied to the stump but become uncomfortable and painful with use. An uncomfortable socket will cause tissue breakown, gait deviations and quite possibly rejection of the appliance, so comfort is a critical factor governing the success of amputee rehabilitation.

\section{Stability}

Is the prosthesis stable when worn by the amputee?

Stability is the key to patient safety. If the appliance is unstable the amputee will fear collapse and ambulation will be severely hindered. The patient must have confidence in the prosthesis and its stability.

The appliance must be aligned carefully and the suspension must not interfere with the stability requirements. In above-knee and hip-disarticulation appliances the use of prosthetic joints makes alignment very important and so it must be checked out very carefully.

\section{Function}

Is the prosthesis of the correct length?

The length of the prosthesis must be correct or the patient's gait will be severely hampered. Gait deviations due to too long a prosthesis are abundant, e.g. circumduction or vaulting, so it is important to check the length of the appliance. This is best carried out in the standing position by placing the thumbs on the anterior superior iliac spines and checking that they are on the same horizontal level.

Can the patient ambulate with his prosthesis? 
Ambulation is the motivating factor behind the fitting of a prosthesis. The functional requirements for gait are not normally very excessive and the amputee should be able to walk with the appliance. Gait deviations can be corrected by modifications to the alignment, suspension or knee mechanism. Some gait problems can be attributed to the lack of experience of the amputee and unfamiliarity with the prosthesis and these can be solved during the training process.

Careful attention has to be given to the problem of stump pistoning (slipping up and down) within the socket during locomotion. Pistoning can be caused by poor socket fitting or inadequate suspension and, if not corrected, can lead to tissue injuries due to the rubbing action. The easiest method of checking piston action is to stand the amputee on his good limb with the prosthesis raised clear of the ground. If a significant gap appears between the socket brim and the stump, then the prosthesis will piston during locomotion.

Can the amputee sit comfortably?

The prosthesis should permit the amputee to sit comfortably. In some cases the suspension system interferes with sitting and this can be a problem. Some prostheses slip off the stump a little on sitting and have to be adjusted when the amputee stands up. This is very common in the suction socket designs and the patient has to reapply suction when he gets up. This is carried out by pressing the stump firmly into the socket and forcing trapped air out of the release valve situated on the distal section of the socket. A rather nasty rasping sound is generally heard when the patient reapplies suction by this method.

It is also worth checking whether the patient can kneel with his device in place, as some occupations such as those of motor mechanic, joiner, or plumber require this.

\section{Cosmesis}

Is the appearance of the prosthesis satisfactory?

Cosmesis is important to every amputee and this aspect should not be underrated. A good appearance is essential to the patient because he has to wear the appliance in everyday activities. If the prosthesis looks bad, it will affect his motivation to use it effectively.

Contemporary appliances can now provide an excellent level of cosmetic restoration because they use soft foam sections and nylon skin-coloured coverings. If the device looks good to the patient his determination to use the prosthesis will increase, and this will help in the training programme. Good cosmesis adds little more to the total price and helps ensure a lower rejection rate.

\section{Workmanship}

Is the prosthesis well made and is it reliable?

Workmanship and reliabiilty are major factors in the success of any appliance. The prosthesis has to be able to stand up to the wear-and-tear of daily activities, and it must maintain its reliability. The appliance should operate smoothly and there should be no excessive noise, rattles or slackness about the device. Suspension straps have to be firmly secured, and the socket must be very smooth inside. The cosmetic coverings must not hinder the operation of the prosthesis by jamming into the joint mechanisms.

\section{Patient Satisfaction}

Is the patient satisfied with' the prosthesis?

This is of course the most important question in any checkout procedure. The patient must be satisfied with the appliance and the comfort, suspension, func- tion, stability, and cosmesis must fulfil his needs, Future problems of rejection of an appliance can usually be traced to the failure to satisfy the patient' needs in the early stages of rehabilitation. It is impor tant to win the confidence of the patient so that $h$ feels free to present his views about the appliance. It is all too easy for the amputee to accept a poorly fitting appliance because he feels obliged to accept it come what may.

There will also certainly be some discomfort with any prosthesis at initial fitting and it must be explained that this is a normal reaction to the device in the early stages. As the patient becomes more accustomed to the prosthesis he will have less problems in using it effectively.

It is essential to build up the patient's confidence in his appliance and any questions about the device have to be answered adequately. There is nothing to hide from the patient and the limitations of the prosthesis should be pointed out clearly. It is easy to give the impression that the prosthesis will permit the patient to do everything that he did prior to his amputation and this is not good practice. There are problems in using any prosthesis and the patient must be made aware that only a determined effort will achieve a successful conclusion to the rehabilitation process.

\section{Stump Care}

There are problems in using a prosthesis in daily activities and both the stump and the prosthesis take a fair degree of punishment in periods of constant use. Like any system involving moving parts, wear-and-tear occurs in use. Early maintenance can prevent problems and make the prosthesis more acceptable to the amputee.

The volume of the stump will not remain constant in daily use of the appliance. Though it can fit really well when initially donned the stump increases in volume as the day proceeds, and can become uncomfortable. This is a fairly normal result of extensive prosthetic use and it is one of the problems in using an appliance. One factor which directly affects the stump-socket relationship is the change in body weight of the amputee. Changes in weight will alter stump volume and it will not be possible to retain a good fit in the prosthetic socket. The amputee must avoid putting on excessive weight as this will lead to an uncomfortable socket fit.

In a lot of cases, stump socks are used between the socket and the skin surface. Good socks are required and they must be washed regularly to keep them clean Replacement must be made when sock wear become irreparable. Filthy ragged stump socks can only lead to future tissue problems, and sock replacement and cleaning should be emphasised.

The stump should be washed carefully at least once a day to remove dead tissue materials and sweat secretions. When washing with a little disinfectant and hot water the tissues can be inspected for skin discolourations, abrasions, grazing, and rough areas. Ulcers should be treated by a physician at the earliest opportunity. It is possible to have an amputee literally walk the stump to a condition of severe ulceration without considering that medical treatment is necessary. Many amputees find that applying some talcum powder to the stump before donning the prosthesis is useful. However, too much powder can have an adverse effect by impairing sweating.

\section{Maintenance of Prosthesis}

The appliance should be examined regularly to see that it is in good condition. Careful attention.must be given to the socket to check for surface discontinuities which will lead to stump problems. Major discontinuities 
like material folds, cracks and rivet failures require attention by the orthopaedic workshops.

The joints, foot mechanism and suspension straps should be free of slackness and noisy operation and all the rivets should be secure. On contemporary, modular pliances there is generally some form of cosmetic covering. Abrasion and tearing of the nylon covering cairly common especially where it passes over prosthetic joints. Severe deterioration of the cosmetic cover theuld be reported to the workshop. On many belowknee appliances soft cushion liners are used as an interface material between the stump and the socket. in general, two materials are used to make the soft liner, i.e. leather and plastic. With constant use the liner becomes discoloured and can develop a pungent odour. Leather liners cannot be washed because of the inherent qualities of the material; however, the plastic liner can be cleaned. Plastic liners are made from a closed-cell material (Pe Lite) which is snowy white in colour. Pe Lite can be washed with hot soapy water to remove discolourations and odours and the liners normally come up like new.

The amputee should not adjust the prosthesis by taking the components apart, as the alignment will be lost. If the alignment is incorrect, the appliance can become very unstable in use. In some cases the patient is expected to adjust the wheel tightening mechanism of his prosthetic knee joint but he should be given instruction in this before being allowed to make any alterations.

\section{Concluding Remarks}

The amputee clinic at Groote Schuur Hospital saw a total of 1594 patients during 1975-1976, and 359 of these were new amputees. The rest were either referrals from day hospitals or they attended of their own volition. In the main these patients attended because of stump pain and/or mechanical problems with the appliance. A large proportion of the problems examined could have been avoided by careful examination at the checkout and by an effective training régime.

Early diagnosis of stump, gait and prosthetic problems is essential and it is a key role for the physiotherapist. If rehabilitation is going to be carried out, then it must be done correctly and this means that the checkout and training procedures cannot be neglected. We have to reduce the number of patients at the clinic sessions so that more time can be allocated to those patients who need detailed evaluation. This can only be done by improving the present rehabilitation process so that fewer patients are referred.

\section{Acknowledgements}

The authors wish to thank the members of the amputee clinic team in Groote Schuur Hospital where this study was carried out.

\section{References}

Murdoch, G. (1970). Prosthetic Orthotic Practice. London, Ed. Arnold Ltd.

\section{FIRST WORLD CONGRESS OF THE COUNCIL FOR EXCEPTIONAL CHILDREN}

The First World Congress of the Council for Exceptional Children will be held at the University of Stirling, Scotland, from June 25th to July Ist 1978. The Congress hopes to examine all aspects of special education for the handicapped child, to appraise and perhaps challenge existing ideas and to evaluate alternatives for the future. Half of each day will be devoted to international panels on different key subjects whilst in the afternoons participants will be allocated to one of up to fifty seminar group meetings according to their previously determined specific fields of interest.

Full details are available from CEC World Congress, 1920 Association Drive, Reston VA 22091, U.S.A. Congress fees are 195,00 U.S. dollars.

\section{POST-GRADUATE COURSE - MANIPULATION OF THE SPINE}

The above course will not be conducted by the Australian Physiotherapy Association in Adelaide in 1978 or 1979 , but it may be resumed in 1980 .

\section{FOREIGN JOURNALS}

Journals of most member associations of W.C.P.T are received by the Editor. These are available upon request.

\section{OORSESE TYDSKRIFTE}

Tydskrifte van meeste lede-verenigings van W.C.P.T word deur die Redaktrise ontvang. Hulle is op versoek beskikbaar.

\section{NOTTCE}

The following Government Gazettes contain important notices for Physiotherapists. These are obtainable from the Government Printers at 20c a copy.

No. 5349 of 3 December 1976: The Professional Board for Physiotherapy; Rules for the Registration of Physiotherapists; Conditions under which Physiotherapists may practice; The scope of Physiotherapy.

No. 5741 of 16 September 1977: Acts of Omissions in respect of which disciplinary steps may be taken; Registration of Physiotherapy students.

No. 5765 of 7 October 1977: Tariff of fees.

\section{KENNISGEWINGS}

Die volgende Staatskoerante bevat belangrike kennisgewings vir Fisioterapeute. Dis beskikbaar van die Staatsdrukkers teen 20 sent per kopie.

No. 5349 van 3 Desember 1976: Die Beroepsraad vir Fisioterapie; Reëls betreffende die Registrasie van Fisioterapeute; Voorwaardes waarop Fisioterapeute hulle beroep mag beoefen; Die Omvang van Fisioterapie.

No. 5741 van 16 September 1977: Handelinge of Versuime ten opsigte waarvan tugstappe gedoen kan word; Registrasie van studente in Fisioterapie.

No. 5765 van 7 Oktober 1977: Geldetarief. 